\title{
OESTROGEN AND PROGESTERONE LEVELS IN THE BLOOD PLASMA OF COWS WITH NORMAL PARTURITION OR WITH A RETAINED PLACENTA
}

\author{
O. AGTHE AND H. P. KOLM \\ Physiologisches Institut, Tierärztliche Hochschule, Hannover, \\ 3 Hannover, Germany
}

(Received 4th October 1974)

According to Aehnelt (1960), retention of the placenta may be due to mechanical, infectious, nutritional or hormonal causes. Hormonal factors were found by McDonald, McNutt \& Nichols (1954) to play an important rôle in the pathogenesis of retention of the placenta in cattle. Although these authors demonstrated that a relationship existed between progesterone and the incidence of retention, they did not report oestrogen and progesterone levels in the blood of the affected cows. It appeared pertinent, therefore, to determine oestrogen and progesterone levels in cows undergoing a normal parturition and puerperium and to compare these data with those obtained for cows in which the placenta was retained.

Blood samples $(20 \mathrm{ml})$ were taken from the jugular veins of fifteen German black pied cows through a fixed plastic catheter twice daily at 06.00 and 18.00 hours from 3 days before until 1 day after parturition (Day $0=$ day of parturition). The blood was collected in centrifuge tubes containing $0.2 \mathrm{ml}$ of a $40 \%$ sodium citrate solution and was immediately centrifuged at $700 \mathrm{~g}$. The plasma was stored at $-20^{\circ} \mathrm{C}$ until it was used for oestrogen and progesterone determinations. All animals gave birth normally after physiological gestation periods ranging from 274 to 285 days. In eleven cows, the placenta was expelled within $6 \mathrm{hr}$ of parturition (control group). In the remaining four animals, it was retained for more than 5 days.

Radioimmunoassay was applied for measuring unconjugated oestrogen and progesterone. For the determination of the immunoreactive oestrogens, rabbit antibodies against $17 \beta$-oestradiol-4-azo-BSA with equal binding affinity to both oestrone and oestradiol- $17 \beta$ were used. No cross-reaction with oestradiol-17 $\alpha$ was observed (Agthe \& Kolm, 1975). Progesterone determinations were carried out according to the method described by Abraham, Swerdloff, Tulchinsky \& Odell (1971), using antibodies against progesterone-11-hemisuccinate-BSA. Gelite column chromatography was, however, replaced by selective extraction by petroleum ether (b.p. 40 to $60^{\circ} \mathrm{C}$ ) as suggested by Johansson (1970).

As shown in Text-fig. 1 the mean \pm S.D. progesterone concentrations in the control group and in cows with a retained placenta continually decreased from Day -2 to $+1(4.1 \pm 1.1 \mathrm{ng} / \mathrm{ml}$ to $0.7 \pm 0.5 \mathrm{ng} / \mathrm{ml}$ and $3.7 \pm 0.6$ to $1.6 \pm 0.3 \mathrm{ng} / \mathrm{ml}$, respectively). Though the difference observed between the cows in the control 
group and those with a retained placenta was relatively small, the decrease of progesterone concentration seemed to be more distinct in the control animals. During the last 3 days of pregnancy, the individual oestrogen levels in cows with

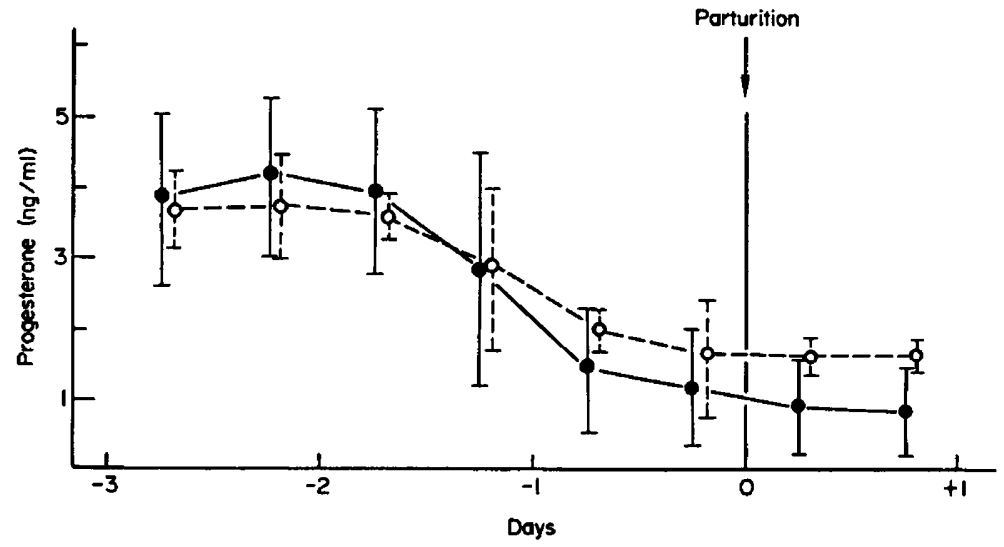

Text-Fig. 1. Progesterone concentrations in peripheral venous plasma around parturition in eleven control cows (-) and four cows each with a retained placenta $(----)$. The points and vertical lines represent means \pm S.D.

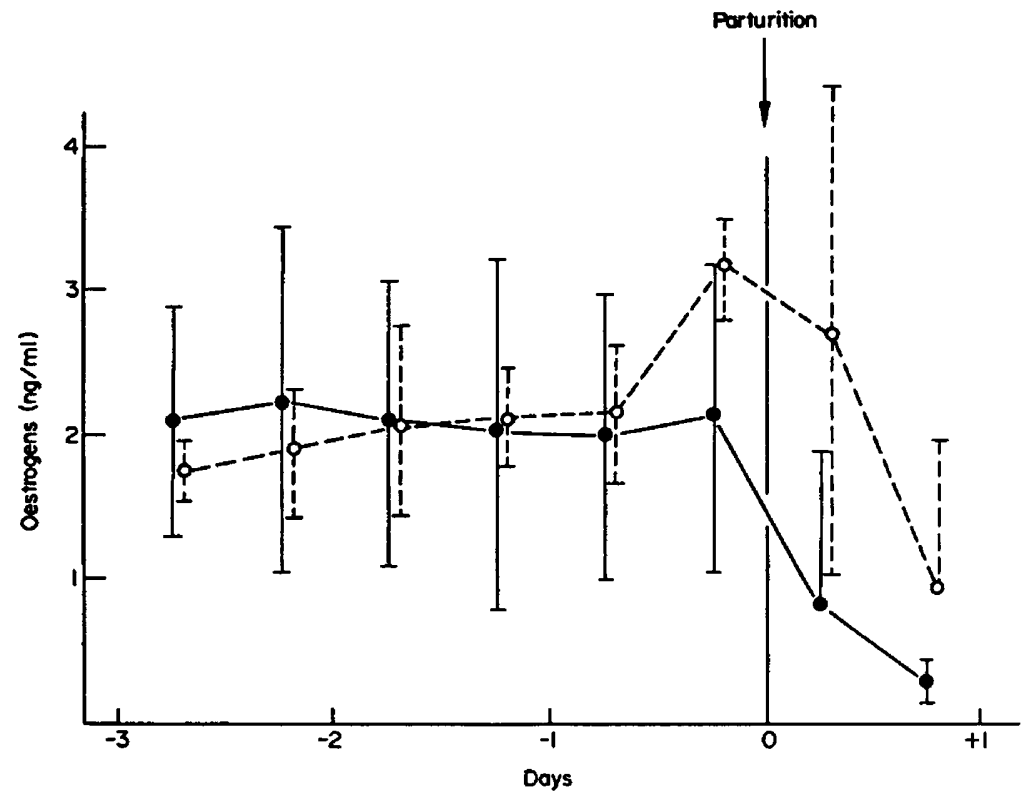

TExT-FIG. 2. Oestrogen concentrations in peripheral venous plasma around parturition in eleven control cows $(-)$ and four cows each with a retained placenta $(---)$. The points and vertical lines represent means \pm S.D.

normally expelled placentae showed no significant deviation from a plateau level. The plateaus were within the range of 1.2 to $4.8 \mathrm{ng} / \mathrm{ml}$, due to significant variations between individual cows $(P<0.001)$. Oestrogen concentrations decreased significantly within $24 \mathrm{hr}$ of parturition, until they reached approxi- 
mately $0.25 \mathrm{ng} / \mathrm{ml}$ (Text-fig. 2). Animals with a retained placenta exhibited a marked increase of oestrogen levels within $12 \mathrm{hr}$ before parturition, followed by a slower decrease during the lst day post partum. In one cow, values were found to be about $2.5 \mathrm{ng} / \mathrm{ml}$ at $20 \mathrm{hr}$ post partum.

The progesterone levels found in control cows were in good agreement with the results obtained by Hoffmann, Schams, Gimenez, Ender, Herrmann \& Karg (1973), Smith, Edgerton, Hafs \& Convey (1973) and Edqvist, Ekman, Gustafsson \& Johansson (1973). These authors also noted a decrease in progesterone concentration about 2 days before parturition. The pattern described for oestrogen levels at the time of normal birth differs, however, from one investigator to another. Robertson (1974) described a continuous increase in the concentrations of oestrone and oestradiol- $17 \beta$ up to parturition while Robinson, Anastassiadis \& Common (1971) found a decrease in total oestrone from 1 to 5 days before parturition. These results agree with those obtained by Smith $e t$ al. (1973) who recognized a slight but significant decline in the levels of oestrone and oestradiol-17 $\beta$, starting about 2 days before parturition. By contrast, Hoffmann et al. (1973) and Edqvist et al. (1973) described oestrone and oestradiol-17 $\beta$ concentrations at constant plateau levels during the last 3 days before birth, as in the present study.

For a further understanding of the rôle of hormones at birth, it is essential to differentiate between the effects of oestrogens and progesterone on the occurrence of a retained placenta and, conversely, the influence of retained fetal membranes on oestrogen and progesterone levels in the cow. From the studies of Ainsworth \& Ryan (1966) and Pierrepoint, Anderson, Griffiths \& Turnbull (1969), it is evident that the fetal placenta is a source of oestrogen in cattle. This could explain the high oestrogen concentrations that we found in the cows with a retained placenta after parturition. The increased oestrogen levels before parturition, together with the reduced fall in the progesterone levels may be the cause of placental retention. It is interesting to note that in cows in which premature parturition was induced by injection of glucocorticoids, an increase in the oestrogen level was observed within $24 \mathrm{hr}$ before parturition, accompanied by a high incidence of placental retention (Adams, 1969; Karg, Böhm, Günzler \& Müller, 1971 ; Edqvist, Ekman, Gustafsson, Jacobsson, Johansson \& Lindell, 1972; Agthe, Grunert, Fadle \& Diez, 1973).

We wish to thank Professor Dr P. W. Jungblut, Max-Planck-Institut für Zellbiologie, Wilhelmshaven, for the oestrogen antiserum used in the above assay. This study was supported by Deutsche Forschungsgemeinschaft.

\section{REFERENCES}

Abraham, G. E., Swerdloff, R., Tulchinsky, D. \& Odell, W. D. (1971) Radioimmunoassay of plasma progesterone. F. clin. Endocr. Metab. 32, 619-624.

Adams, W. M. (1969) The elective induction of labour and parturition in cattle. J. Am. vet. med. Ass. $154,261-265$.

Aehnelt, E. (1960) In Richter Götze, Tiergeburtshilfe, 2nd edn, p. 620. Paul Parey, Berlin and Hamburg.

Agthe, O., Grunert, E., Fadle, W. A. \& Diez, G. (1973) Klinische und hormonanalytische Untersuchungen bei der corticoidinduzierten Geburt des Rindes. Zuchthyg. FortpflStör. Besam. Haustiere, 8, 119-124. 
AgthE, O. \& Kolm, H. P. (1975) Radioimmunologische Bestimmung physiologischer Östrogenkonzentrationen im Blutplasma von Kühen um den Geburtstermin. Zuchthyg. FortpfiStör. Besam. Haustiere (in press).

Ainsworth, L. \& RYAN, K. J. (1966) Steroid hormone transformations by endocrine organs from pregnant mammals. I. Estrogen biosynthesis by mammalian placental preparations in vitro. Endocrinology, 79, 875-883.

Edquist, L. E., Ekman, L., Gustafsson, B., Jacobsson, S. O., Johansson, E. D. B. \& Lindell, J. O. (1972) Peripheral plasma levels of oestrone and progesterone in pregnant cows treated with dexamethasone. Acta endocr., Copenh. 71, 731-742.

Edevist, L. E., Ekman, L., Gustafsson, B. \& Johansson, E. D. B. (1973) Peripheral plasma levels of oestrogens and progesterone during late bovine pregnancy. Acta endocr., Copenh. 72, 81-88.

Hopfmann, B., Schams, D., Gimenez, T., Ender, M. L., Herrmann, C. \& Karg, H. (1973) Changes of progesterone, total oestrogens, corticosteroids, prolactin and LH in bovine peripheral plasma around parturition with special reference to the effect of exogenous corticoids and a prolactin inhibitor respectively. Acta endocr., Copenh. 73, 385-395.

Johansson, E. D. B. (1970) A simplified procedure for the assay of progesterone. Acta endocr., Copenh. Suppl. 147, 188-203.

KaRG, H., BöHM, S., GüNZLER, O. \& MülLeR, S. (1971) Erfahrungen über die Geburtseinleitung beim Rind mit Glucocorticoiden. Dt. tierärztl. Wschr. 78, 35-39.

McDonald, L. E., MaNutt, S. H. \& Nichols, R. E. (1954) Retained placenta. Experimental production and prevention. Am. J. vet. Res. 15, 22-24.

Pierrepoint, C. B., Anderson, A. B. M., Griffiths, K. \& Turnbull, A. C. (1969) Metabolism of C-19 steroids by foetal cotyledons from the bovine placenta at term. Res. vet. Sci. 10, 477-479.

Robertson, H. A. (1974) Changes in the concentration of unconjugated oestrone, oestradiol-17 $\alpha$ and oestradiol- $17 \beta$ in the maternal plasma of the pregnant cow in relation to the initiation of parturition and lactation. 7. Reprod. Fert. 36, 1-7.

Robinson, R., Anastassiadis, P. A. \& Common, R. H. (1971) Estrone concentrations in the peripheral blood of pregnant cows. II. Values around parturition. F. Dairy Sci. 54, 1832-1834.

Smith, V. G., Edgerton, L. A., Hafs, H. D. \& Convey, E. M. (1973) Bovine serum estrogens, progestins and glucocorticoids during late pregnancy, parturition and early lactation. F. Anim. Sci. 36, 391-396. 